\title{
Air Pump Assembly Device
}

National Cancer Institute

\section{Source}

National Cancer Institute. Air Pump Assembly Device. NCI Thesaurus. Code C49811.

A composite part of an air pump or a larger device that includes an air pump. 